\title{
A expansão do ensino profissional na rede pública estadual de educação do Paraná - 2003- 2006
}

\author{
Autora: Amelia Cristina Titericz Pinheiro \\ Nível: Mestrado (PPGE/UFPR) \\ Orientadora: Profa. Dra. Taís Moura Tavares
}

Esta pesquisa buscou encontrar as razões que determinaram a retomada do ensino profissional na rede pública de educação do Paraná como política, período 2003-2006, bem como sua expansão; por conseqüência, também se analisaram fundamentos desta política. Foram utilizadas como principais estratégias metodológicas: análise de documentos oficiais, de levantamento de dados estatísticos, de questionário aplicado a diretores ou coordenadores de colégios com ensino profissional de Curitiba, de entrevistas com a gestora da rede pública estadual de educação profissional do Paraná e com representante da APP-Sindicato. Os dados foram analisados tomando o materialismo histórico dialético como referencial teóricometodológico. As razões observadas foram: a indução que as políticas federais para o ensino profissional produzem sobre a política estadual; a necessidade dos governos, nacional e estadual, de dar uma resposta política a um problema social de raiz econômica, o desemprego, e assim buscar legitimidade; a herança histórica do estado do Paraná de reestruturação de cursos profissionalizantes nos governos do PMDB; a pressão dos movimentos sociais; a oposição ideológicopartidária deste governo, 2003-2006, ao seu antecessor, o qual quase eliminou a possibilidade de cursos profissionalizantes, na rede pública estadual; pressão do mercado de trabalho, que também atinge a opinião pública, principalmente pela mídia, apontando para a necessidade de formação específica para o trabalhador e ao mesmo tempo formação geral, o que causa também entrecruzamento de concepções no transcorrer da política. 